\title{
LA FELICIDAD COMO IDEAL DE LA IMAGINACIÓN ${ }^{1}$
}

\author{
Soledad García Ferrer
}

RESUMEN: En este artículo intentamos desarrollar mínimamente los cinco discursos sobre la felicidad que hemos encontrado en la obra de Kant. Los hemos encontrado con dificultad, porque no se trata de discursos ordenados ni continuados a lo largo de sus páginas, sino más bien de sugerencias que van apareciendo de vez en cuando al hilo de otras reflexiones. La felicidad se dibuja como totalidad, como un concepto indeterminado, como el polo opuesto a la cultura, como sentimiento y como bien. Aunque no se trate de discursos bien enlazados, es posible seguirles la pista a lo largo de los textos. No obstante, hay otra sugerencia que Kant nos proporciona y que él mismo no desarrolla en absoluto: según ella la felicidad sería el ideal de la imaginación. Este sexto discurso no pronunciado tal vez pudiera suministrar la clave que nos sirva para encontrar la coherencia de los demás.

PALABRAS CLAVE: Imaginación. Ideal. A priori.

Los lectores de Kant encontramos a menudo irritante el modo en que él mismo y sus comentaristas despachan el problema de la felicidad, como si fuera un asunto, no solo molesto, sino de fácil comprensión. Y al menos lo segundo no lo es en absoluto. En cuanto se intenta buscar un concepto coherente de lo que Kant entiende por felicidad — aunque solamente sea para contemplar el aspecto

${ }^{1}$ Este artículo quiere resumir la Tesis Doctoral titulada La doctrina kantiana de la felicidad: la felicidad como ideal de la imaginación, que fue dirigida por Juan Manuel Navarro Cordón y defendida en diciembre de 2010 en la Universidad Complutense de Madrid. Pero la complejidad de los asuntos tratados hace que en este resumen haya que renunciar a apartados completos del citado trabajo. Para una información más detallada habrá que acudir al texto original.

2 Soledad García Ferrer (Madrid, España, 1961) estudió Filosofía en la Universidad Autónoma de Madrid y Filología Alemana en la Universidad Complutense de Madrid. Su campo de estudio se centra en la Filosofía alemana de Kant a Nietzsche. Ha publicado diversos artículos, como el titulado "La diversa consideración del objeto de conocimiento por parte de Schopenhauer y de Kant: una cuestión de punto de vista" (en Anthropos, Número 6, 1993) o "El problema de la felicidad: lo que ya desde siempre quedó fuera del rigorismo kantiano" (en NAVARRO CORDÓN, J.M.; SÁNCHEZ MADRID, N. (Ed.). Ética y metafísica. Sobre el ser del deber ser. Madrid: Biblioteca Nueva, 2010). Ha participado como ponente en diversos Congresos de Filosofía, como en el $28^{\circ}$ Congreso de Filósofos Jóvenes celebrado en Málaga en 1991 con la conferencia titulada "El pensamiento de la muerte en el Zaratustra de Nietzsche" o en el I Congreso Iberoamericano de Filosofía celebrado en Alcalá de Henares (Madrid) en 2002. Pertenece al Grupo de Investigación UCM "Metafísica, Crítica y Política" bajo la dirección de Juan Manuel Navarro Cordón. En 2010 defendió su tesis doctoral, titulada La teoría kantiana de la felicidad: la felicidad como ideal de la imaginación. Actualmente compagina sus estudios con la docencia en la Enseñanza Media. 
de aquello que aparece tachado como fundamento de determinación de la acción moral - lo que se encuentra es una pluralidad de perspectivas, de modos de decir, de discursos.

Encontramos seis modos diferentes de hablar de la felicidad en la obra de Kant: la felicidad como totalidad, como concepto indeterminado, como lo opuesto a la cultura, como sentimiento y como bien. Y también encontramos una definición que aparece de pasada una sola vez en la Fundamentación de la metafísica de las costumbres y según la cual la felicidad es el ideal de la imaginación. ${ }^{3}$ Vamos a presentar someramente estos seis discursos tal y como les hemos seguido el hilo a lo largo de la obra de Kant y al final vamos a arriesgar una hipótesis: que la felicidad es, ante todo, el ideal de la imaginación y, precisamente por eso, es también todas las demás cosas que leemos en los demás discursos. Pero para hacerlo tendremos que entender el papel fundamental que juegan la imaginación y la síntesis en la constitución de la felicidad. Esto nos llevará a la observación 7202, un texto no publicado por Kant en el que, sin embargo, creemos haber encontrado algunas claves que nos pueden ayudar a manejarnos dentro de esta multiplicidad de caras desde las que nos mira y nos hace señas la felicidad.

Pero vayamos por partes: ¿cómo se puede hablar de la felicidad?

\section{LOS DISCURSOS DE LA FELICIDAD}

Ya en el Canon de la Crítica de la Razón Pura aparecía la que ha pasado a la historia como la definición más manejada de la felicidad: ${ }^{4}$ la satisfacción de todas nuestras inclinaciones tanto en su complejidad como en cuanto a su grado como respecto a su duración. Se trata de la satisfacción completa y definitiva de todas nuestras inclinaciones: intensive, protensive y extensive. En otros pasajes

\footnotetext{
${ }^{3}$ Kant im Kontext II. C Karsten Worm - InfoSoftWare 2003. Buch: Grundlegung zur Metaphysike der Sitten (1785). Kapitel: I. Übergang von der gemeinen sittlichen Vernunfterkenntniß zur philosophischen. Basis-Ausgabe: Akad. (1905ff.), S. IV:418. Bis: S. IV:419. Salvo indicación contraria, las traducciones de los textos de Kant son de la autora de este trabajo.

${ }^{4}$ Glïckseligkeit ist die Befriedigung aller unserer Neigungen (sowobl extensive der Mannigfaltigkeit derselben, als intensive dem Grade und auch protensive der Dauer nach) [Kritike der reinen Vernunft (1787). Kapitel: Kanon der reinen Vernunft. 2. Abschn. Von dem Ideal des höchsten Guts [...]. Basis-Ausgabe: Akad. (1905ff.), S. B:834.] He aquí la definición que Kant usa con mayor frecuencia, aunque no sea necesariamente la que tiene más incidencia en su trabajo. En esto estamos de acuerdo con Daniel O'Connor (Kant's Conception of Happiness, en The Journal of Value Inquiry 16, 1982), que presenta en su artículo una visión sintética del concepto de felicidad en Kant en un intento de defenderlo de las críticas que se le han hecho de incoherencia y de rigorismo. O'Connor defiende una interpretación del discurso de Kant sobre la felicidad bastante más unitaria que la que nosotros nos disponemos a desplegar en esta sección.
} 
también aparece el concepto de totalidad. ${ }^{5} \mathrm{Y}$, como siempre que hablamos de la totalidad, esto nos remite a la dialéctica de la razón y a la totalidad de condiciones que la razón nos exige suponer como dada si es que pretendemos que la cadena silogística encargada de buscar un principio incondicionado al dato condicionado tenga sentido. La universalitas exige una universitas, una totalidad efectivamente real de las condiciones para un condicionado dado que en este caso es nuestra inclinación de hecho, siempre relativa y condicionada. Ahora bien, el problema surge cuando consideramos que al hablar de la felicidad y de las inclinaciones se hace muy difícil admitir que pueda darse un absoluto, pues ¿no se caracterizan las inclinaciones precisamente por ser relativas, subjetivas, fluctuantes? ¿Cómo se va a absolutizar un terreno tan resbaladizo como el de las inclinaciones? Cuando en el Canon de la razón pura Kant presentaba a la moralidad como la causa de la felicidad en un hipotético mundo moral siempre mencionaba un reparto o una proporción; ${ }^{6}$ pero esta partición, por muy racional que pudiera ser y precisamente por eso, ¿no estaría reñida con la idea de lo absoluto, con el principio de la totalidad que tenemos que adscribir a las inclinaciones? No sabemos qué cuesta más trabajo admitir: la absolutización de lo relativo o la repartición de la totalidad. Pero, en cualquier caso, dentro de este proceso de absolutización de las inclinaciones parece que nos hemos dejado en el camino a la felicidad misma y lo que vamos a obtener es más bien "un-poco-de-alguna-felicidad-de-vez-en-cuando" y no la felicidad tal como la hemos definido desde el principio.

Si ahora acudimos en busca de orientación a los tres adverbios que acompañan a nuestra definición, encontramos que el primero de ellos, extensive, nos remite a una multiplicidad heterogénea, a una Mannigfaltigkeitt, a una complejidad

${ }^{5}$ En la segunda parte de la Fundamentación de la metafísica de las costumbres afirma Kant que "[...] para la idea de felicidad se exige un todo absoluto, un máximo de bienestar en mi estado presente y en todo estado futuro" [Grundlegung zur Metaphysik der Sitten (1785). Kapitel: II. Übergang von der populären sittlichen Weltweisheit zur Metaphysik der Sitten. Basis-Ausgabe: Akad. (1905ff.), S. IV:418.] Cf. Kritik der praktischen Vernunft (1788). Kapitel: \3. Lehrsatz II. Basis-Ausgabe: Akad. (1905ff.), S. V:22u.: "Ahora bien, la felicidad es la conciencia de un ser racional de la aceptabilidad (Annehmlichkeit) de la vida que acompaña ininterrumpidamente a su existencia entera." Los términos utilizados por Kant son Totalität, Ganze, Vollständigkeit y a veces simplemente Maximum.

${ }^{6}$ Dice, por ejemplo, que la ley moral "[...] abstrae de las inclinaciones y los medios naturales para satisfacerlas y considera solamente la libertad de un ser racional en general y las condiciones necesarias únicamente bajo las cuales ella concuerda con el reparto (Austeilung) de la felicidad según principios." [Kritik der reinen Vernunft (1787), Basis-Ausgabe: Akad. (1905ff.), S. B:834.] ¿Cómo puede haber un reparto de la felicidad en el que previamente se abstraiga de las inclinaciones? ¿No acaba de definir Kant la felicidad precisamente en términos de inclinación?

${ }^{7}$ Mannigfaltigkeit ¿no podría ser otro nombre del polýtropoi con el que Nietzsche nombraba la vida en ese reino de poder absoluto del conocimiento? Denn man frage sich nur gründlicb: "warum willst du nicht täuschen?" namentlich wenn es den Anschein haben sollte, —und es hat den Anschein! - als wenn das Leben auf Anschein, ich meine auf Irrtum, Betrug, Verstellung, Blendung, Selbstverblendung angelegt wäre, und wenn 
múltiple en la que los muchos pliegues y arrugas impiden la reducción a lo mismo $y$, por tanto, la generalización de un concepto. La felicidad incluye, entonces, una multitud innumerable de repliegues y recovecos. Lejos de la lisura diáfana, ajena a la simplicidad, siempre oculta algún aspecto, siempre reserva alguna faceta. Y no podría ser de otro modo tratándose de las inclinaciones, pues la inclinación hay que entenderla como la desviación con respecto a un eje, la curva de una trayectoria que se retuerce en voluta sobre sí misma y configura un interior al mismo tiempo que lo oculta, el clinamen que provoca que otros móviles también pierdan su verticalidad y se desordenen en cadena, el movimiento primero que al desviarse inicia una cadena fractal que no tiene fin.

Intensive remite al grado o a la profundidad de la satisfacción. La tensión en este caso no va dirigida hacia el exterior (extensive), sino hacia el interior de la satisfacción misma para asegurar el grado de su cumplimiento, el logro de una total satisfacción, de un apaciguamiento o aquietamiento en sí mismo completo. No sólo habría de conseguir, pues, el contento de cualquier inclinación por compleja y difícil que fuera, sino que este contento habría de ser acabado o consumado.

Protensive se refiere a la duración, a la tendencia hacia adelante en el tiempo, a la prolongación de esa satisfacción. Encontrándonos en el terreno de las sensaciones no puede extrañarnos este absoluto temporal, pues la receptividad es la del sentido interno, que sucede y se desarrolla en el tiempo y no en el espacio.

Pues bien, lo que nos han mostrado estos tres adverbios es que la satisfacción que se identifica con la felicidad tendría que abarcar cualquier objeto de la inclinación, por intrincado y recóndito que fuera, tendría que ser en sí misma completa y tendría que perdurar indefinidamente en el tiempo. Por estas tres notas se define la felicidad o el encontrarse bien. Pero con ellas lo que obtenemos es una perspectiva del ser feliz como ser tendido (extendido, intendido y protendido) o tenso, como un modo de ser que no puede encontrar asiento en sí mismo, sino que tiene que emigrar a otra parte, tiene que lanzarse afuera para encontrar quietud o apaciguamiento, siendo esa parte a la que ha de lanzarse absolutamente heterogénea —no sólo con respecto a él, sino en sí misma-, absolutamente insondable — pues cuando se zambulle en su interior para alcanzar el fondo de su satisfacción es una sima insondable lo que encuentra-y absolutamente lejana en el tiempo. La felicidad queda determinada, pues — si es que se puede utilizar esta palabra en este caso-, como tensión, como tirantez, como intencionalidad.

andrerseits tatsächlich die grosse Form des Lebens sich immer auf der Seite der unbedenklichsten polytropoi gezeigt hat. (La gaya ciencia \344 (Sämtliche Werke, Bd 3, Berlin, dtv 1980, s. 576) Las múltiples arrugas (de las inclinaciones) serían las múltiples caras o facetas (de la vida). 
En el mismo texto de la Fundamentación que hemos citado ya aparece la caracterización de la felicidad en otra de sus facetas, a saber, como concepto indeterminado:

Sólo que es una desgracia que el concepto de felicidad sea un concepto tan indeterminado que, aun cuando todo ser humano desea alcanzarla, sin embargo, no puede decir nunca con precisión y de acuerdo consigo mismo lo que propiamente quiere y desea. ${ }^{8}$

La indeterminación del concepto de felicidad tiene dos vertientes: por un lado, ningún hombre puede decir qué es lo que propiamente quiere y desea; por otro lado, tampoco puede decirlo con un mínimo de acuerdo consigo mismo, de modo coherente o congruente consigo mismo. Indeterminación objetiva tanto como subjetiva, pues, que juntas constituyen los dos aspectos del deseo. La razón que en este pasaje sirve para explicar esta indeterminación es que, por una parte, los elementos de los que se compone la idea de la felicidad son de procedencia empírica, están extraídos de la experiencia; pero, por otra parte, como hemos visto anteriormente, la felicidad es un máximo o un absoluto. La felicidad tendría que ser un concepto empírico, es decir, tendría que recibir su materia de la experiencia. Pero esto no es posible, puesto que incluye la nota de la totalidad de una serie infinita esta vez por el lado de las consecuencias. Y el problema radica, entonces, en el contraste entre la infinitud de la serie y la finitud de nuestro conocimiento, es decir, de la experiencia. Kant lo plantea como el contraste entre la omnisciencia y la experiencia. Este contraste da paso a la indeterminación subjetiva o incongruencia del deseo consigo mismo. Nosotros, seres finitos, incapaces de calar el infinito, no podemos tener un concepto coherente de la felicidad. Y la indeterminación en la que lo dejamos lo pone a merced de los bandazos de la incoherencia, de los que Kant extrae los ejemplos en los que va desgranando la vanidad de nuestros deseos. ${ }^{9}$ En todos ellos asistimos

8 Allein es ist ein Unglück, daß der Begriff der Glückseligkeit ein so unbestimmter Begriff ist, daß, obgleich jeder Mensch zu dieser zu gelangen wünscht, er doch niemals bestimmt und mit sich selbst einstimmig sagen kann, was er eigentlich wünsche und wolle. [Grundlegung zur Metaphysike der Sitten (1785). Kapitel: II. Übergang von der populären sittlichen Weltweisheit zur Metaphysik der Sitten. Basis-Ausgabe: Akad. (1905ff.), S. IV:418] En la Crítica de la razón práctica \8 Observación II (S. V:36) se aduce este motivo para rechazar que el principio de la felicidad sea apto para proporcionar leyes prácticas universales (universelle), aunque se admite que las pueda proporcionar reglas generales (generelle): pues "[...] el juicio depende de la opinión de cada cual, que además es muy variable", a lo que se añade que el hecho de que se trate de un objeto cuya experiencia se recomienda hace que la diferencia de los juicios no tenga fin (die Verscbiedenheit des Urtheils endlos sein).

${ }^{9}$ Merece la pena reproducir un fragmento del excelente comentario que escribe Norbert Hinske al texto de Kant al que nos estamos refiriendo a lo largo de esta sección: "Denn jene Glücksvorstellung ist für sich genommen nur ein leeren Traum von Glïck. Trockener formuliert: Sie ist nur ein rein formales Begriff. Jene inhaltliche 
a la preeminencia de un jirón de experiencia en detrimento de otras zonas que permanecen en principio ignoradas pero que posteriormente cobran un doloroso relieve y hacen huir la felicidad que nos prometíamos. En conjunto podemos decir que se trata de inclinaciones cuya satisfacción es incoherente con la de otras que también reclaman la suya en una pugna constante y sin tregua. No se ve cómo podría haber, en este terreno, regla alguna; ni siquiera cómo podría haber consejos de prudencia que no fueran los puramente represivos.

Ahora bien, si el concepto de felicidad incluye elementos empíricos y también comprende otro ingrediente fundamental que no puede ser empírico, a saber, el de totalidad o infinito, esto hace que no podamos clasificarla, en definitiva, como un concepto empírico. Y, dado que tampoco se nos ocurriría considerarla un concepto puro, eso significa lanzarnos a la busca de otro tipo de conceptos mixtos o híbridos. Los encontramos mencionados (de pasada) en un importante pasaje del capítulo II de la Analítica de los conceptos de la Crítica de la razón pura, en el momento en que Kant decide valerse de la distinción entre quid iuris y quid facti, procedente del lenguaje jurídico, y emprender la deducción —es decir: la demostración del derecho o pretensión- de los conceptos puros del entendimiento. Es en este momento en el que alude a un buen número de conceptos de los que nadie exige una deducción y de los que se hace uso comúnmente en la confianza de que podríamos recurrir a la experiencia para deducirlos si hubiera necesidad. Se trata de conceptos empíricos, susceptibles de una deducción empírica. Pues bien, entre ellos circulan otros a los que Kant denomina conceptos usurpados:

También hay entre ellos conceptos usurpados, como por ejemplo felicidad y destino, que ciertamente circulan con una tolerancia casi universal a pesar de que a veces caen bajo las exigencias de la cuestión quid iuris?; y entonces se encuentra uno no poco azorado por causa de la deducción, al no poder aducir ningún fundamento de derecho ni procedente de la experiencia ni procedente de la razón por el cual se ponga de manifiesto que está autorizado su uso. ${ }^{10}$

Füllung dieses Traumes aber ist so vielen biographischen Zufäligkeiten, aber auch so vielen objektiven Unwägbarkeiten unterworfen, daß darüber überhaupt keine allgemeinverbindliche Aussage möglich ist. In Wabrheit stochert der Mensch bei der Suche nach Glück unentwegt im Nebel herum. Ein Hafen ist nicht in Sicht. Wer definitiv zu wissen meint, was Glück ist, hat sich selbst noch nicht begriffen. Die Einsicht in den wabren Sinn von Glück verlangte "Allwissenheit". Wahres Glück gehört zugespitzt formuliert, in den Bereich der Noumena" "Die Ratschläge der Klugheit" im Ganzen der Grundlegung. Kant und die Ethik der Griechen, 3. Abschnitt: Xenophon, en HÖFFE, Ottfried (Hrsg.). Grundlegung zur Metaphysike der Sitten: ein kooperativer Kommentar, Frankfurt a. M.: Klostermann, 1989). Como veremos en seguida, si bien es cierto que nos movemos en el terreno de los noúmenos, se trata en el caso de la felicidad de un noúmeno muy especial.

${ }^{10}$ Es giebt indessen auch usurpirte Begriffe, wie etwa Glück, Schicksal, die zwar mit fast allgemeiner Nachsicht berumlaufen, aber doch bisweilen durch die Frage: quid iuris, in Anspruch genommen werden; da man alsdann wegen der Deduction derselben in nicht geringe Verlegenheit geräth, indem man keinen deutlichen Rechtsgrund weder aus der 
La felicidad es, pues, un concepto usurpado, o tal vez habría que entender que es un concepto usurpador, que roba a otro el derecho o la legitimidad, ${ }^{11}$ que ocupa una función que no le corresponde a él, como un Sosias que se arrogara un derecho permanente. La prueba de que lo hace bastante bien es que circula desapercibido y tolerado y en general se lo confunde con su doble. Ahora bien: ¿cuál es su doble? ¿por quién se hace pasar la felicidad? ¿A quién está sustituyendo ilegítimamente el destino, concepto que no podía por menos de aparecer como acompañante de la felicidad? ¿Quién debería ocupar este lugar que estos dos pseudoconceptos están usurpando?

¿O más bien ocurre que se cuelan en él y pretender hacerlo suyo porque se trata de un lugar que está vacío y tendría que permanecer vacante? Felicidad y destino ocupan el lugar del concepto, se lo reparten entre ellos. Y su impostura no es, por lo común, ni descubierta ni denunciada. ¿No será porque en realidad están haciendo las veces de nadie, como un Sosias cuyo rey hubiese muerto y al que nadie reclamara ya ni su disfraz ni su máscara? La interpretación habitual coloca a la felicidad y al destino las máscaras convencionales de estos conceptos muertos y sólo cuando se da esta situación, dentro de esta farsa conceptual, se dispone a emitir imperativos analítico / hipotéticos de alcance universal que nos quieren convertir en sujetos hábiles en felicidad, peritos en dominar los medios del goce como si tuviéramos claros los fines. La filosofía de Kant se puede considerar como una acusación dirigida a los usurpadores, como una exigencia de credenciales a los impostores, como el final de la mascarada. Al juzgar sobre su credibilidad, al dudar de sus pretensiones, al desconfiar de su presencia y, en último término, al planear arrojarlos del trono que pretendían detentar, nos coloca ante el trono vacío, ante la carencia de fines, en la no presencia, en el no lugar de la Verlegenheit.

Un tercer discurso de la felicidad la sitúa en el extremo diametralmente opuesto a la cultura y en vecindad con la rudeza. La felicidad consistiría en seguir la voz natural del instinto y esto explicaría la misología que convirtió en un crimen el uso de la razón en los tiempos cercanos al origen de la humanidad. ${ }^{12}$ No obstante,

Erfahrung, noch der Vernunft anfübren kann, dadurch die Befugniß ibres Gebrauchs deutlich würde. [Kritik. der reinen Vernunft (1787). Kapitel: V. d. Deduction der reinen Verstandesbegriffe. \$13. Von den Principien einer tr. Deduction überhaupt. Basis-Ausgabe: Akad. (1905ff.), S. B:117.]

${ }^{11}$ Usurpar procede de usus y rapere $=$ arrebatar un uso o un derecho a alguien.

${ }^{12}$ Vid. Grundlegung zur Metaphysike der Sitten (1785). Kapitel: I. Übergang von der gemeinen sittlichen Vernunfterkenntniß zur philosophischen. Basis-Ausgabe: Akad. (1905ff.), S. IV:395. Bis: S. IV:396 y Kleine Schriften (1782-1800). Kapitel: Muthmaßlicher Anfang der Menschengeschichte. Basis-Ausgabe: Akad. (1905ff.), S. VIII:113. Como es sabido, el término aparece en Platón: Fedón 89d-90d. (trad. Luis Gil, Madrid, Tecnos, 2007). A la misología se llega en Platón porque los que se dedican a razonar el pro y el contra de las cosas "[...] terminan por creer que han adquirido la suprema sabiduría y que son los únicos que han comprendido que ni en las cosas hay nada de ellas que sea sano ni cierto, ni tampoco en 
este discurso sobre la felicidad es, al menos, ambivalente, pues por una parte evoca aires rousseaunianos y por otra parte niega taxativamente la posibilidad del retorno a ese estado primitivo calificándola de deseo vano. El \83 de la Crítica del Juicio podría considerarse el texto más representativo de esta segunda postura, pues en él encontramos que "[...] el concepto de felicidad no es un concepto que el hombre abstraiga de alguna manera de sus instintos y lo saque así de la animalidad que hay en él mismo", ${ }^{13}$ sino que es el resultado de un trabajo del entendimiento entretejido (verwickelt) con la sensibilidad y la imaginación. En lugar de ser un resultado del instinto o de la naturaleza, es un proyecto (Entwurf) que el hombre diseña por sí mismo y al cual quiere —inútilmente - que se adecúe su estado bajo condiciones meramente empíricas. Entendimiento, imaginación, voluntad y sensibilidad colaboran en la elaboración de esa idea que, evidentemente, no puede caracterizarse por su sencillez, sino más bien por ser la maraña de imágenes y deseos que estamos intentando desenredar en este trabajo.

El resultado es un concepto tan fluctuante (schwankender Begriff) que, incluso si la naturaleza estuviera ordenada enteramente para adecuarse a él, no podría satisfacerlo siendo como es un sistema de leyes, por lo que no nos ha de extrañar que, entre tanta vacilación, se dedique también a coquetear con el pasado e imagine que la felicidad se encuentra en el retorno a la naturaleza. La felicidad es una idea variable, caprichosa, arbitraria, que ni siquiera sería capaz de dar órdenes a una naturaleza puesta a su servicio. Nada queda en ella de esa voz de la naturaleza que (nos) daba órdenes a los animales.

La felicidad, pues, se va desarrollando al paso de la cultura, prestándole a ésta la materia que ella se encarga de configurar utilizando los recursos que la naturaleza le proporciona. En realidad, el vacío de la cultura se corresponde con el vacío de la felicidad, pues mientras la primera tiene un vacío formal, la felicidad es el vacío de la indeterminación; pero lo que está claro es que la felicidad proporciona los fines, pues se entiende como

los razonamientos, sino que la realidad en su totalidad va y viene de arriba para abajo, ni más ni menos que si estuviera en el Euripo, y no permanece quieta ni un momento en ningún punto". Este ajetreo de los razonamientos corresponde, en el caso de los razonamientos sobre la felicidad — los únicos de los que hablamos aquí - al ajetreo de las inclinaciones. Por lo demás, la misología es resultado, en los dos autores, de la decepción de unas esperanzas desmesuradas.

${ }^{13}$ Der Begriff der Glückeseligkeit ist nicht ein solcher, den der Mensch etwa von seinen Instincten abstrabirt und so aus der Thierheit in ihm selbst hernimmt; sondern ist eine bloße Idee eines Zustandes, welcher er den letzteren unter bloß empirischen Bedingungen (welches unmöglich ist) adäquat machen will. Er entwirft sie sich selbst und zwar auf so verschiedene Art durch seinen mit der Einbildungskraft und den Sinnen verwickelten Verstand[...] [Kritik der Urtheilskeraft (1790). Kapitel: \83. Von dem letzten Zwecke der Natur als eines teleologischen Systems. Basis-Ausgabe: Akad. (1905ff.), S. V:430] 
[...] la suma (Inbegriff ) de todos los fines humanos posibles por obra de la naturaleza tanto en el hombre como fuera del hombre. Ella es la materia de todos los fines del hombre en la tierra.

La oposición entre felicidad y cultura en este $\$ 83$ de la Crítica del Juicio, pues, lo es entre materia y forma. La forma se concibe como actividad, como formación o configuración de ese material que, inevitablemente, necesita un tiempo. Y este es el tiempo de la historia. Por eso ese mismo texto nos presenta un recorrido por los hitos fundamentales de la historia de la cultura. En el opúsculo de 1786 Comienzo presunto de la bistoria bumana también se examina esta perspectiva temporal, pero limitándose a los orígenes. La felicidad inocente que se nos presentaba en la Fundamentación de la metafisica de las costumbres constituye ahora el objeto del tercer anhelo —o, más bien, añoranza vana ${ }^{14}$ — que encontramos cuando analizamos la historia de los hombres: el de regresar a una edad de oro

[...] en la que nos libraríamos de todas esas exigencias artificiosas con las que nos sobrecarga el lujo, en la que nos contentaríamos con las exigencias de la naturaleza y habría una continua igualdad de los hombres, una paz perpetua entre ellos, en una palabra, el puro goce de una vida despreocupada, perezosamente soñadora o derrochada en juegos infantiles. ${ }^{15}$

El enfoque de este estado primitivo es diametralmente opuesto aquí y en la Fundamentación de la metafísica de las costumbres, como puede apreciarse, pues ahora el anhelo que lleva a pensar en él no es otra cosa que la expresión del tedio del hombre civilizado y de la pereza que igualmente le caracteriza: frente al trabajo que le exige la cultura, él añora la simplicidad infantil; frente a la acción que se le reclama, él prefiere retornar a la pasividad y al descanso; y, es más, frente al conflicto, él prefiere una paz arcádica que, a diferencia de la que Kant propone en otros textos, no le suponía ningún esfuerzo. Pero, aparte de ilustrarnos con respecto a nuestro modo de pensar, el contenido de este ensueño carece de correlato objetivo, pues la mentada época de sencillez e inocencia constituye el estado inicial de la humanidad y "[...] el hombre no puede mantenerse en él

${ }^{14}$ Véase, para esta tipología del deseo, el comienzo del $\$ 73$ de la Antropología en sentido pragmático.

${ }^{15}$ Der dritte Wunsch, oder vielmehr die leere Sehnsucht (denn man ist sich bewußt, daß das Gewünschte uns niemals zu Theil werden kann) ist das Schattenbild des von Dichtern so gepriesenen goldenen Zeitalters: wo eine Entledigung von allem eingebildeten Bedürnisse, das uns die Üppigkeit aufladet, sein soll, eine Genügsamkeit mit dem bloßen Bedarf der Natur, eine durchgängige Gleichheit der Menschen, ein immerwährender Friede unter ihnen, mit einem Worte der reine Genuß eines sorgenfreien, in Faulheit verträumten oder mit kindischem Spiel vertändelten Lebens/...] [Kleine Schriften (1782-1800). Kapitel: Muthmaßlicher Anfang der Menschengeschichte. Basis-Ausgabe: Akad. (1905ff.), S. VIII:122.] 
porque no le satisface; y menos aún se encuentra inclinado a retornar a él". ${ }^{16} \mathrm{La}$ completa descripción de la historia presunta de la humanidad habla en contra de que nos encontremos ante un verdadero deseo. Se trata de una añoranza vacía, como la de la infancia.

Ahora bien, este estado primitivo es el que se encontraba guiado por "[...] el instinto, esta voz de Dios, a quien obedecen todos los animales" o "[...] esta llamada de la naturaleza" ${ }^{17}$ cuyos mandatos están dirigidos principalmente a la conservación del individuo (instinto de nutrición) y a la conservación de la especie (instinto sexual). ${ }^{18} \mathrm{El}$ instinto actuaba de indicador de conducta que guiaba el deseo hacia unos objetos en concreto. Al renunciar a esta guía, el hombre

\begin{abstract}
$[\ldots]$ estaba como al borde de un abismo, pues a partir de los objetos concretos de sus deseos, que hasta ahora le había señalado el instinto, se le abría una infinitud de ellos en cuya elección él no sabía todavía manejarse; y, una vez probado este estado de libertad, ya le fue imposible volver otra vez a la servidumbre bajo el dominio del instinto. ${ }^{19}$
\end{abstract}

La experiencia de la civilización fue al mismo tiempo la experiencia de la miseria desde el momento en que el hombre comenzó a ocuparse de sí mismo y de su felicidad, se encontró con la afección de su propio carácter, se percató de la contingencia de la vida y de que la alternativa al instinto y a las pasiones eran

${ }^{16}$ [...] der Mensch könne sich darin nicht erhalten, darum weil er ihm nicht genügt; noch weniger sei er geneigt, jemals wieder in denselben zurückzukehren; [Ebd. Basis-Ausgabe: Akad. (1905ff.), S. VIII:122 Bis: S. VIII:123] Si no estamos ante una inclinación es porque no se trata de un apetito sensible, no porque esta añoranza no sea habitual.

17 Der Instinct, diese Stimme Gottes, der alle Thiere gehorchen [...7 So lange der unerfahrne Mensch diesem Rufe der Natur gehorchte [...][Ebd. Basis-Ausgabe: Akad. (1905ff.), S. VIII:111.]

18 Sobre el instinto, véase Reflexionen zur Anthropologie. Kapitel: [Nachlaß] Collegentwürfe aus den 80er Jahren. Basis-Ausgabe: Akad. (1905ff.), S. XV: 859: "La naturaleza ha dispuesto los instintos para sus grandes fines." En este mismo pasaje afirma taxativamente que los animales no conocen la felicidad. Cf. ibidem Basis-Ausgabe: Akad. (1905ff.), S. XV:840, donde contrapone los instintos a las inclinaciones y repite la animalidad del instinto: "El deseo que es causa duradera de la voluntad o el deseo habitual es la inclinación. El que entra rápidamente y sin causa visible es el instinto (precede al conocimiento del objeto). Los instintos son animales, ocurrencias y antojos igualmente irregulares." Hay que tener en cuenta que unas veces está refiriéndose al instinto en general y otras a la presencia actual del instinto en el hombre. Esto podría explicar la aparente incoherencia entre unos textos y otros.

19 Er stand gleichsam am Rande eines Abgrundes; denn aus einzelnen Gegenständen seiner Begierde, die ihm bisher der Instinct angewiesen hatte, war ihm eine Unendlichkeit derselben eröffnet, in deren Wabl er sich noch gar nicht zu finden wußte; und aus diesem einmal gekosteten Stande der Freibeit war es ihm gleichwohl jetat unmöglich, in den der Dienstbarkeit (unter der Herrschaft des Instincts) wieder zurück zu kehren. [Kleine Schriften (1782-1800). Kapitel: Muthmaßlicher Anfang der Menschengeschichte. Basis-Ausgabe: Akad. (1905ff.), S. VIII:112] 
la náusea o el tedio. ${ }^{20} \mathrm{La}$ humanidad comenzó cuando la razón empezó a rebullir (sich regen) y el animal empezó a desobedecer esta voz, esta llamada o este mandato del instinto. En el asunto de la nutrición, la desobediencia abrió una serie infinita de posibilidades al tiempo que volvía la elección más difícil por indeterminada. En el caso del instinto sexual, fueron el alejamiento del objeto y la abstención consiguiente los que acrecentaron, de nuevo hasta el infinito, las posibilidades de satisfacción, al mismo tiempo que las prolongaron en el tiempo y las volvieron más complejas y refinadas. No nos puede sorprender que aparezcan de nuevo la tensión, la diferencia, el alejamiento, la mediación. El objeto del deseo se aleja, se vuelve extraño y diverso, se esconde, se vela; y así aprende a seducir. El horizonte de posibilidades se abre, se abisma, se desdibuja, se curva, pierde nitidez. ¿Cómo podíamos pensar que la felicidad estaba en el estado anterior? ¿O tal vez se trate de otro de sus escondites?

En toda esta transformación es la razón la que lleva la iniciativa, aunque ayudada por la imaginación:

Pero es una propiedad de la razón el que, con ayuda de la imaginación, pueda simular deseos, no sólo en ausencia de un impulso natural a ellos dirigido, sino incluso en contra de él, los cuales reciben al principio el nombre de concupiscencia y desde los que poco a poco se incuba todo un enjambre de inclinaciones ineludibles e incluso antinaturales bajo el nombre de lujo. ${ }^{21}$

Es la razón la que va multiplicando las inclinaciones en un proceso que, en lugar de restarles fuerza, las torna insoslayables. Es ella la que produce, en esta multiplicación, no sólo el enjambre de necesidades de la técnica y del lujo, sino también el amor, el gusto por la belleza y la decencia, que es la base de la sociabilidad. Es ella la que abre también la reflexiva expectación del futuro con todas sus amenazas. Prohíbe el retorno al estado de inocencia primitivo, pues apremia al hombre a desarrollar sus capacidades.

Consideradas así las cosas, podríamos decir que la noción de felicidad próxima a la misología que estamos analizando sería aquella nostalgia vana de la edad de oro o también, como nos encontramos en este texto, aquel rechazo y criminalización del uso de la razón al que los hombres llegaron y llegan siempre

20 Vid. KRÜGER, Gerhard: Critique et morale chez Kant. Traduit par M. Regnier, préface d'Eric Weil. Paris: Beauchesne, 1961, p. 80.

21 Allein es ist eine Eigenschaft der Vernunft, daß sie Begierden mit Beibülfe der Einbildungskraft nicht allein obne einen darauf gerichteten Naturtrieb, sondern sogar wider denselben erkü̈steln kann, welche im Anfange den Namen der Lüsternheit bekommen, wodurch aber nach und nach ein ganzer Schwarm entbehrlicher, ja sogar naturwidriger Neigungen unter der Benennung der Üppigkeit ausgebeckt wird.[Kleine Schriften (1782-1800). Kapitel: Muthmaßlicher Anfang der Menschengeschichte. Basis-Ausgabe: Akad. (1905ff.), S. VIII:111] 
al comprobar cómo este uso les pone delante, no sólo la preocupación por todos los cuidados y esfuerzos a los que tienen que atender, no sólo las infinitas posibilidades de elección y todos los peligros que conllevan, sino el abismo aún más insondable de la muerte:

\begin{abstract}
Los dos previeron en fin con temor en el fondo del cuadro, después una vida llena de fatigas, aquello que ciertamente alcanza a todos los animales pero que a ninguno preocupa, a saber, la muerte; y les pareció reprobable el uso de la razón que tantos males les causaba y la convirtieron en un crimen. ${ }^{22}$
\end{abstract}

Se rechaza la razón, pues, porque nos hace patente nuestra finitud al confrontarnos con esa infinitud de posibilidades de las que los animales y los niños están a resguardo. Porque nos abre el horizonte al infinito y entonces es cuando podemos verle el fondo al cuadro y darnos cuenta de que esa infinitud es, sin dejar de serlo, limitada. O porque nos expulsa de ese abrigo de la inocencia y nos deja abandonados en lo inhóspito, en ese paréntesis infinito entre dos puntos ineludibles. Y en ese desamparo lleno de cuidados tenemos que bregar para hacernos una vida. El anhelo de la felicidad originaria sería el anhelo fetal del útero de la naturaleza. Y el rechazo de la razón y de la libertad no es otra cosa que el espanto de la muerte.

En un cuarto discurso la felicidad se presenta como sentimiento. El teorema II de la Analítica de la Crítica de la razón práctica está dedicado precisamente a este asunto en la medida en que pretende homogeneizar todos aquellos fundamentos de determinación de la voluntad que históricamente — con posterioridad a los griegos - han sido diferenciados de manera inconsecuente, a juicio de Kant, y que tienen su raíz común en el sentimiento, sea cual sea el origen de la representación a la que este sentimiento esté ligado. La imagen que en este texto utiliza Kant para expresar la homogeneidad del sentimiento es la del oro, que, en cuanto dinero, sólo tiene valor por el hecho de que sea reconocido y valorado por alguien hasta tal punto que esté dispuesto a adquirirlo a cambio de otra cosa; su valor, pues, no depende de su procedencia, sino de su recepción. Pues bien, lo mismo ocurre con los principios subjetivos de la voluntad: pueden ser de origen intelectual, instintivo, incluso racional; pueden ser más o menos refinados, pero lo que importa es cómo son recibidos por el sentimiento, cómo le afectan. Y en este aspecto sólo cabe una diferenciación meramente cuantitativa, como ocurría con el oro: pueden suscitar un placer mayor o menor, más o menos

${ }^{22}$ Beide saben nach einem mühseligen Leben noch im Hintergrunde des Gemäldes das, was zwar alle Thiere unvermeidlich trifft, obne sie doch zu bekë̈mmern, nämlich den Tod, mit Furcht voraus und schienen sich den Gebrauch der Vernunft, die ibnen alle diese Übel verursacbt, zu verweisen und zum Verbrechen ₹u machen. [Ebd. Basis-Ausgabe: Akad. (1905ff.), S. VIII:113] 
duradero, más o menos variado, pero siempre de la misma clase. Sin embargo, estos placeres tocan cada vez de diversa manera al sentimiento y es esta variación la que hace el cálculo imposible:

En su Ensayo de sabiduría mundana moral el Señor de Maupertuis quiso estimar la suma de la felicidad de la vida humana de acuerdo con los mismos conceptos y no podía ser estimada de otro modo; pero esta tarea es irresoluble para los hombres porque solo se pueden sumar sensaciones del mismo tipo, pero el sentimiento en el estado tan complicado de la vida parece ser muy diferente según la complejidad de los afectos. El cálculo le dio a este hombre ilustre un facit negativo, en lo cual, sin embargo, discrepo de él. ${ }^{23}$

De nuevo la Mannigfaltigkeit, que no sólo se refiere, entonces — como habíamos visto-, a las inclinaciones, sino a los sentimientos mismos de los que ellas surgen en ese estado tan complejo, tan enmarañado, tan entretejido de afectos que es la vida tal y como tenemos que representárnosla cuando ella deja de ser ese reinado ameno del instinto que contemplábamos en el discurso anterior de la felicidad.

El cálculo con el oro es difícil que sea fiable, de modo que la comparación sigue siendo eficaz: uno no puede determinar cómo podrá cambiar su oro; tampoco podemos saber con certeza el precio de un placer en el mercado sentimental, pues todo depende de la acogida que tenga en ese momento en nuestra subjetividad.

En qué haya de poner cada cual su felicidad depende del sentimiento peculiar de placer y dolor de cada cual e incluso, en un mismo sujeto, de la diversidad de lo que exija la variación de ese sentimiento; y así una ley subjetivamente necesaria (como ley natural) es objetivamente un principio práctico muy contingente, que puede ser y ha de ser muy diferente en diferentes sujetos $y$, por ende, no puede nunca proporcionar una ley. ${ }^{24}$

\footnotetext{
${ }^{23}$ Nach dergleichen Begriffen sucbte der Herr v. Maupertuis in seinem Versuche der moralischen Weltweisheit die Summe der Glückseligkeit des menschlichen Lebens zu schätzen, und sie kann auch nicht anders gescbätz̨t werden, nur daß diese Aufgabe für Menschen unauflöslich ist, weil nur gleichartige Empfindungen können in Summen gezogen werden, das Gefübl aber in dem sehr verwickelten Zustande des Lebens nach der Mannigfaltigkeit der Rührungen sehr verschieden scheint. Der Calcul gab diesem gelehrten Manne ein negatives Facit, worin ich ibm gleichwobl nicht beistimme. [Versuch [über] den Begriff der negativen Größen [...] (1763). Kapitel: 2. Beispiele aus der Weltweisheit [...], darin der Begriff der negativen Größen vorkommt. Basis-Ausgabe: Akad. (1905ff.), S. II:181-182.]

${ }^{24}$ Worin nämlich jeder seine Glückseligkeit zu setzen habe, kommt auf jedes sein besonderes Gefühl der Lust und Unlust an, und selbst in einem und demselben Subject auf die Verschiedenheit des Bedürfnisses nach den Abänderungen dieses Gefühls, und ein subjectiv nothwendiges Gesetz. (als Naturgesetz) ist also objectiv ein gar sehr zufälliges praktisches Princip, das in verschiedenen Subjecten sehr verschieden sein kann und muß, mithin niemals ein Gesetr abgeben kann, [...][Kritik der praktischen Vernunft (1788). Kapitel: \ 3. Lehrsatz II. Basis-Ausgabe: Akad. (1905ff.), S. $\mathrm{V}: 25$.
} 
De manera que la naturaleza nos encomienda y nos manda entrar en este comercio de los sentimientos, en este mercado anárquico en el que no se puede cerrar ningún trato, pues la volubilidad de nuestro sentir no deja tiempo ni lugar para ello. El trato con nosotros mismos es, efectivamente, el más difícil de ajustar. La satisfacción, no ya con nuestro estado, sino con nuestra completa existencia, no podemos conseguirla ni con todo el oro del mundo:

Pues la satisfacción con su entera existencia no es como una posesión originaria y una bienaventuranza (Seligkeit), que presupondría una conciencia de su autosuficiencia independiente, sino un problema con que su naturaleza finita le ha lastrado $[\ldots]^{25}$

Para que pudiera haber trato sería necesario un cierto saber acerca del sentimiento. Y, como ya sabemos, el sentimiento no puede convertirse nunca en objeto de conocimiento, ni siquiera de un conocimiento de nosotros mismos. Él contiene ese elemento opaco del sujeto que no puede ser presentado ante sí mismo. Ahora bien, si la felicidad surge del sentimiento, ahí tenemos la razón de que no pueda haber una ciencia de la felicidad, pues no puede haber ciencia de los sentimientos. Llegamos, por consiguiente, a la misma conclusión que hemos obtenido en discursos anteriores: que de la felicidad no puede haber otra cosa que consejos y que no podemos ser versados en esta disciplina. Si antes llegábamos a esta conclusión a partir de su indeterminación, también podemos llegar a partir del hecho de que nos movemos en el terreno de los sentimientos. No sólo porque sus límites tiendan continuamente a lo máximo o absoluto, sino por otra razón más: porque, al surgir de un sentimiento, la felicidad no puede nunca objetivarse, sino que permanece continuamente del lado del sujeto. Y este lado nos es desconocido; lo único que sabemos de él es que constituye un terreno móvil, inestable, en alteración continua, problemático, donde no se puede instituir ninguna ley, ni siquiera se puede llegar a ningún pacto ni contrato, pero al que, no obstante, la ley de la naturaleza nos entrega de manera inevitable.

Pero ¿qué se siente en el sentimiento de la felicidad? Placer, sí, pero ¿placer con qué? Y aquí no podemos mencionar ningún contenido, pues lo único que podríamos dar sería una lista de placeres continuamente variables que iría cambiando en función directa de la complicación de la vida. Así que la respuesta sólo puede ser formal y en este punto el concepto al que se apela es el de acuerdo o consenso.

De aquí surge otra de las definiciones kantianas de la felicidad más conocidas:

${ }^{25}$ Ibidem 
La felicidad es el estado de un ser racional en el mundo al cual, en la totalidad de su existencia, todo le va según su deseo y voluntad y descansa, pues, en el acuerdo de la naturaleza con la totalidad de sus fines y del mismo modo con el fundamento de determinación esencial de su voluntad. ${ }^{26}$

La felicidad sería, según ella, el resultado en el sujeto del acuerdo entre la voluntad y el mundo, como un modo de encontrarse el ser racional, una Stimmung de la razón que sólo podría aparecer si se diera la coincidencia entre lo que ella esencialmente es y el mundo, si los dos fueran al unísono, si se sintonizaran. La felicidad como modo de encontrarse la razón depende de que el mundo responda siempre a su voluntad y a sus deseos, de que le sea dócil; depende de la mansedumbre del mundo. Y, uniendo este pasaje que acabamos de leer con lo que hemos dicho anteriormente en este apartado sobre la volubilidad del sentimiento, llegamos a la conclusión de que la imposibilidad del acuerdo con el mundo depende de la imposibilidad del acuerdo — previo— con nosotros mismos.

Un quinto discurso habla de la felicidad entendida como bien:

Por tanto, cuando se trata de la felicidad que yo debo promover como mi fin propio, ha de tratarse de la felicidad de los demás, cuyo fin (permitido) hago con ello también el mío. Lo que deba contarse como su felicidad se les deja a ellos juzgarlo; a mí sólo me corresponde rehusar algo de aquello que yo no considere como tal siempre que ellos no tengan derecho a exigírmelo como suyo. ${ }^{27}$

El texto se inscribe en la polémica sobre si habría que considerar la felicidad como incluida en la perfección. Kant es partidario de separarlas cuidadosamente, hasta el punto de que la búsqueda de la felicidad propia no puede ser considerada un fin que es al mismo tiempo deber, mientras que la búsqueda de la felicidad ajena sí es un fin debido. El mismo fin puede pasar de ser contradictorio a ser obligado dependiendo de su referencia. La búsqueda de la felicidad ha de estar, pues, claramente bien enfocada o dirigida.

${ }^{26}$ Glückseligkeit ist der Zustand eines vernünftigen Wesens in der Welt, dem es, im Ganzen seiner Existen₹, alles nach Wunsch und Willen geht, und berubet also auf der Übereinstimmung der Natur zu seinem ganzen Zwecke, imgleichen zum wesentlichen Bestimmungsgrude seines Willens. [Ebd. (1788). Kapitel: V. Das Dasein Gottes, als ein Postulat der reinen praktischen Vernunft. Basis-Ausgabe: Akad. (1905ff.), S. V:124u.]

${ }^{27}$ Wenn es also auf Glückeseligkeit ankommt, worauf als meinen Zweck. hinzuwirken es Pflicht sein soll, so muß es die Glückseligkeit anderer Menschen sein, deren (erlaubten) Zweck ich hiemit auch zu dem meinigen mache. Was diese ₹u ihrer Glückseligkeit zä̈hlen mögen, bleibt ihnen selbst zu beurtheilen überlassen; nur daß mir auch zusteht manches zu weigern, was sie dazu rechnen, was ich aber nicht dafür halte, wenn sie sonst kein Recht haben es als das Ihrige von mir zu fordern. [Die Metaphysik der Sitten (1798), Kapitel: B. Fremde Glückseligkeit. Basis-Ausgabe: Akad. (1905ff.), S. VI:388] 
No tendremos tanta claridad, en cambio, cuando queramos indagar dentro de este fin, pues, como acabamos de leer, cada cual ha de considerar qué queda incluido en su felicidad y, dentro de esta amplitud, que sabemos ilimitada, solo cabe rehusar al fin ajeno en función de mi propio parecer sobre este asunto. Con lo que venimos a parar a la consabida confrontación de opiniones sobre lo que es la felicidad, discusión que desdibuja mi obligación y sólo la deja brillar claramente en aquellos casos en que se me reclame lo que es del otro: su propiedad. Entonces la discusión cesa, pues la propiedad ajena es incuestionable e indiscutible. Se podría decir, pues, que la propia felicidad la puede proponer solo uno mismo, pero esa propuesta tiene que ser ratificada por el que tiene en su mano el poder de concederla, que puede tener otra opinión sobre el asunto.

Kant dedica todo el primer capítulo de la segunda parte de la "Doctrina ética elemental" de la Metafísica de las costumbres a tratar los deberes hacia los demás considerados únicamente como hombres, haciendo abstracción de su estado. Se trata de una parte extensa y fundamental de esta obra en la que defiende el concepto de beneficencia (Wobltätigkeit =hacer el bien) considerando que el de benevolencia (Woblwollen =querer el bien) no es suficiente en la Teoría de la Virtud, pues es exigible "[...] una benevolencia activa, práctica, que consiste en proponerse como fin el bien y la salud del otro (hacer el bien)". ${ }^{28}$ El fundamento de toda esta parte de la Metafísica de las costumbres nos lo proporciona la segunda sección de la Fundamentación de la metafísica de las costumbres, en donde, al introducir la segunda fórmula del imperativo categórico, de la que continuamente se hace uso en aquel libro, se presenta el concepto de fin, definido como aquello que "[...] le sirve a la voluntad como fundamento objetivo de su autodeterminación" 29 , y se encuentra, además, que existe un fin objetivo, es decir, que tiene un valor absoluto como fin: la naturaleza racional. Pues bien, si la naturaleza racional es un fin en sí misma - prosigue el argumento_-, de ahí extraemos una nueva fórmula que se refiere a los mismos ejemplos que la primera y que implica que

$[\ldots]$ con respecto al deber meritorio para con los demás, el fin natural que todos los hombres tienen es la felicidad propia. Ahora bien, la humanidad ciertamente podría mantenerse aunque nadie aportara nada a la felicidad de los demás, con tal de que por prescripción no le sustrajera tampoco nada; pero, si cada uno no procurara promover los fines de los otros hombres tanto

${ }^{28}$ [...] ein thätiges, praktisches Woblwollen, sich das Wobl und Heil des Anderen zum Zweck zu machen, (das Woblthun) [Ibidem (1798). Kapitel: $\ 28$ [Tugendlehre]. Basis-Ausgabe: Akad. (1905ff.), S. VI:452.] Recordemos que es en este plano objetual de Wobl/Übel, en esta modalidad del bien, en el que hemos situado la felicidad, aunque ella pretenda extender su dominio a lo permanente de la existencia.

${ }^{29}$ Nun ist das, was dem Willen zum objectiven Grunde seiner Selbstbestimmung dient, der Zweck [...] [Grundlegung zur Metaphysike der Sitten (1785). Kapitel: II. Übergang von der populären sittlichen Weltweisheit zur Metaphysik der Sitten. Basis-Ausgabe: Akad. (1905ff.), S. IV:427.] 
como está en su mano, habría solamente un acuerdo negativo y no positivo con la humanidad como fin en sí mismo. Pues los fines del sujeto que es fin en sí mismo tienen que ser, en lo posible, también fines míos si es que aquella representación ha de producir todo su efecto en mí. ${ }^{30}$

En efecto, si hace unas páginas veíamos que la felicidad consistía en un acuerdo entre el deseo y la voluntad, por una parte, y el mundo, por la otra, entre lo que podría ser el protagonista y su escena, ahora estamos mencionando a los personajes que configuran esa escena, esa circunstancia, y que solamente si procuran promover activamente el bien de ese protagonista, solo si colaboran o toman parte en la consecución de su fin, se convertirán en facilidades para su felicidad. Y es la representación de la naturaleza racional en general, o de la humanidad, la que lleva a esa colaboración. De lo contrario, se quedaría sin producir su efecto: inoperante, estéril, inane.

La búsqueda de la felicidad de los demás es el efecto máximo de la idea de humanidad y le sirve a cada uno como fundamento objetivo de autodeterminación. Nos encontramos, pues, en el ámbito de la razón práctica, de la libertad, de la razón a priori; pero, en la medida en que hemos aportado un contenido concreto a esta voluntad, nos estaríamos alejando de la razón pura a priori, que sólo considera lo puramente formal, el lado objetivo de la determinación de la voluntad. ${ }^{31} \mathrm{Si}$ aludimos a la conocida distinción — que aparece en la Crítica de la razón pura B3entre conocimientos a priori y conocimientos puros a priori, podemos afirmar que la Selbstzweckformel, al contener en sí un concepto empírico, es a priori, pero no pura a priori. Pero más de que concepto empírico habría que hablar en este caso de un puesto vacío (Leerstelle) que solamente podremos llenar con conceptos de la antropología empírica, que se refieren al homo phaenomenon. Únicamente este conocimiento empírico puede dar contenido a lo que se nos ordena imponernos como un fin, pues hemos de recordar lo que hace un momento decíamos: que el fin del que estamos hablando sólo puede surgir en el seno de una discusión obligada en la que se está poniendo en juego el deber y la humanidad. Y la

30 [...] in Betreff der verdienstlichen Pflicht gegen andere ist der Naturzweck, den alle Menschen haben, ibre eigene Glückseligkeit. Nun würde zwar die Menschbeit bestehen können, wenn niemand zu des andern Glückseligkeit was beitrüge, dabei aber ibr nichts vorsetzlich entzöge; allein es ist dieses doch nur eine negative und nicht positive Übereinstimmung zur Menschbeit als Zweck an sich selbst, wenn jedermann auch nicht die Zwecke anderer, so viel an ihm ist, zu befördern trachtete. Denn das Subject, welches Zweck an sich selbst ist, dessen Zwecke müssen, wenn jene Vorstellung bei mir alle Wirkung thun soll, auch, so viel möglich, meine Zwecke sein. [Ebd. Basis-Ausgabe: Akad. (1905ff.), S. IV:430.]

${ }^{31}$ Ebd. Basis-Ausgabe: Akad. (1905ff.), S. IV:431. Véase sobre esta distinción el artículo de Friedo Ricken: Homo noumenon und homo phaenomenon, en: HÖFFE, Ottfried (Hrsg.). Grundlegung zur Metaphysik der Sitten: ein kooperativer Kommentar. Frankfurt a.M.: Klostermann, 1989. 
confrontación de pareceres no debería extrañarnos, pues es la verbalización de la discrepancia que alberga el concepto de felicidad. Lo que hace Kant al convertir la felicidad en bien es elevar la indeterminación que la constituye al plano de la discusión racional, al plano de la confrontación de opiniones, al plano del lógos. No hemos abandonado, pues, el problema de la felicidad. No le hemos vuelto la espalda ni tampoco hemos pretendido resolverlo. Más bien lo hemos reconocido como tal, lo hemos asumido. Al elevarlo no lo hemos suprimido, sino que lo hemos incorporado a la razón práctica y le hemos dado el rango de fin que es deber para todos los seres racionales, y no solo para los hombres.

Pero lo dicho hasta ahora — no lo olvidemos — se refiere a los deberes para con los demás. Pues bien, ¿ंes un deber buscar la propia felicidad? Anteriormente hemos advertido que no, y Kant explica cuidadosamente la contradicción en que se incurriría si se pretendiera convertir en un fin debido aquello a lo que nos lleva naturalmente la inclinación, es decir, si se confundieran los fines morales con los naturales. ${ }^{32}$ No obstante, sus palabras resultan equívocas, a pesar de todas sus precauciones, sobre todo cuando está en discusión hasta qué punto la obligación de promover la felicidad ajena puede implicar el sacrificio de la propia:

Darse una buena vida, tanto como sea necesario para poder encontrar en la
vida un gozo (pero sin cuidarse del cuerpo hasta llegar a la molicie) pertenece
a los deberes para con uno mismo; su contrario es privarse por avaricia de lo
necesario para el alegre disfrute de la vida o renunciar al disfrute de la alegría de
la vida por una disciplina exagerada (entusiasta) de sus inclinaciones naturales. ${ }^{33}$

En este texto no se hace ninguna mención a que se trate de un deber indirecto o a que se trate de un medio, sino que se incluye decididamente la felicidad propia, en el sentido más físico de la palabra — pues se refiere a las inclinaciones - dentro de los deberes del hombre para consigo mismo. Y se mencionan dos vicios contrarios a ese deber: uno que tiene que ver con la cuestión de la riqueza y el gasto y el otro que se refiere a desoír las inclinaciones naturales.

El texto en el que aparece con más extensión la felicidad propia considerada como bien está en la primera sección de la Fundamentación de la metafísica de las costumbres.

${ }^{32}$ Die Metaphysik der Sitten (1798). Kapitel: IV. Welche sind die Zwecke, die zugleich Pflichten sind?. Basis-Ausgabe: Akad. (1905ff.), S. VI:386.

33 Sich selber gütlich thun, so weit als nöthig ist, um nur am Leben ein Vergnügen zu finden, (seinen Leib, doch nicht bis zur Weichlichkeit zu pflegen) gehört zu den Pflichten gegen sich selbst; — deren Gegentheil ist: sich aus Geiz (sklavisch) des zum frohen Genuß des Lebens Nothwendigen oder aus übertriebener Disciplin seiner natürlichen Neigungen (schwärmerisch) sich des Genusses der Lebensfreuden zu berauben, welches beides der Pflicht des Menschen gegen sich selbst widerstreitet. [Ibidem, Kapitel: A. Von der Pflicht der Wohlthätigkeit. \29. Basis-Ausgabe: Akad. (1905ff.), S. VI:452uu.] 


\begin{abstract}
Asegurar la felicidad propia es un deber (al menos indirecto), pues la carencia de satisfacción con el propio estado, el apremio de muchos cuidados en medio de exigencias que no han sido calmadas, podría convertirse fácilmente en una gran tentación para pasar por alto los deberes. Pero, aun sin considerar el deber, todos los hombres tienen ya por sí mismos la inclinación más poderosa y más íntima hacia la felicidad porque en esa idea se reúnen en una suma todas las inclinaciones. No obstante, el precepto de la felicidad está constituido en su mayor parte de tal modo que hace un gran quebranto a algunas inclinaciones y, sin embargo, el hombre no puede hacerse bajo el nombre de felicidad un concepto determinado y seguro de la suma de la satisfacción de todas; de ahí que no haya que asombrarse de que una inclinación única y determinada en cuanto a aquello que ella promete y el tiempo en que puede ser alcanzada la satisfacción, pueda preponderar sobre una idea vacilante $[. . .]^{34}$
\end{abstract}

A continuación se habla del enfermo de gota. En este caso se observa que el concepto de felicidad es tan vacilante que puede hacer que incluso lo más cercano a nosotros, nuestro propio cuerpo, se nos vuelva extraño y, siguiendo una inclinación suya, enjuiciemos que su salud no forma parte de nuestra felicidad. Cuando la naturaleza de este concepto tan fluctuante, en sus infinitas variaciones, llega a la autoaniquilación, cuando el diálogo con uno mismo se ha roto, es cuando hay que imponerse la propia felicidad (la propia salud, el cuidado de sî) como un deber.

\title{
El IDEAL DE LA IMAGINACIÓN
}

Ahora no estamos ante un discurso como los demás, pues solo podemos hablar de un discurso sugerido, pero no pronunciado, de un discurso silenciado, que queda pendiente en la obra de Kant y que precisamente por eso reclama de nosotros una labor de interpretación, no solo de lo que pueda significar, sino del hecho de que nunca haya sido formulado.

El texto fundamental al que debemos recurrir es el de la segunda sección de la Fundamentación de la metafísica de las costumbres, en el se argumenta en torno a si es posible un imperativo categórico que ordene buscar la felicidad. Lo que se

\footnotetext{
34 Seine eigene Glückseligkeit sichern, ist Pflicht (wenigstens indirect), denn der Mangel der Zufriedenheit mit seinem Zustande in einem Gedränge von vielen Sorgen und mitten unter unbefriedigten Bedürfnissen könnte leicht eine große Versuchung zu Übertretung der Pflichten werden. Aber auch obne bier auf Pflicht zu sehen, haben alle Menschen schon von selbst die mächtigste und innigste Neigung zur Glückseligkeit, weil sich gerade in dieser Idee alle Neigungen zu einer Summe vereinigen. Nur ist die Vorschrift der Glückseligkeit mehrentheils so beschaffen, daß sie einigen Neigungen großen Abbruch thut und doch der Mensch sich von der Summe der Befriedigung aller unter dem Namen der Glückseligkeit keinen bestimmten und sichern Begriff machen kann; daher nicht zu verwundern ist, wie eine einqige in Ansehung dessen, was sie verheißt, und der Zeit, worin ihre Befriedigung erbalten werden kann, bestimmte Neigung eine schwankende Idee überwiegen könne[...][Grundlegung zur Metaphysik der Sitten (1785). Kapitel: I. Übergang von der gemeinen sittlichen Vernunfterkenntniß zur philosophischen. Basis-Ausgabe: Akad. (1905ff.), S. IV:399.]
} 
demuestra es que sobre este asunto solo se pueden formular imperativos hipotéticos, bien que asertóricos: los llamados "consejos de la prudencia" (= Klugheit), a los que en la Primera Introducción a la Crítica del juicio se denominará "imperativos pragmáticos", y se subsumirán bajo los técnicos o referidos al arte, aun cuando el fin que se propongan, a saber, la felicidad, sea subjetivamente necesario.

\begin{abstract}
De aquí se sigue que los imperativos de la prudencia, hablando con rigor, no ordenan, esto es, no pueden presentar acciones objetivas como prácticamente necesarias; que han de considerarse más bien como consejos (consilia) que como mandatos (praecepta) de la razón; que la tarea de determinar segura y universalmente qué acción fomentará la felicidad de un ser racional es completamente irresoluble; por consiguiente, no es posible un imperativo que tenga esas miras y que mande en sentido estricto hacer aquello que produce felicidad porque la felicidad no es un ideal de la razón, sino de la imaginación, que descansa en fundamentos empíricos de los cuales en vano se espera que determinen una acción por la cual se alcanzaría la totalidad de una serie de consecuencias de hecho infinita. ${ }^{35}$
\end{abstract}

Encontramos reunidos en este fragmento algunos de los discursos de la felicidad que hemos venido escuchando: la felicidad como concepto indeterminado confluye ahora con la felicidad como totalidad de la serie de consecuencias. También aparece la incoherencia entre el origen empírico de la noción de felicidad y su pretensión de abrazar esta totalidad infinita y, por tanto, inabarcable. Pero cuando se apunta al porqué de todos estos rasgos aparece un elemento nuevo: la felicidad es un ideal de la imaginación. Y aparece, podría decirse, como modo de dar cuenta o, al menos, de hacerse cargo de una imposibilidad: la de que exista un imperativo de la felicidad. Si conseguimos definir mejor este elemento tal vez accedamos a la razón última que explique todas las dificultades con las que nos hemos ido encontrando a lo largo de todos sus discursos.

Y para hacerlo tenemos que confrontar el ideal de la imaginación con el ideal de la razón. Si la felicidad fuera un ideal de la razón se podría determinar, pero, dado que es un ideal de la imaginación, es, como ya sabemos, un concepto indeterminado. Dejando un instante aparte lo que es un ideal y fijándonos en la

${ }^{35}$ Hieraus folgt, daß die Imperativen der Klugheit, genau zu reden, gar nicht gebieten, d.i. Handlungen objectiv als praktisch-nothwendig darstellen, können, daß sie eher für Anrathungen (consilia)als Gebote (praecepta)der Vernunft zu halten sind, daß die Aufgabe: sicher und allgemein zu bestimmen, welche Handlung die Glückseligkeit eines vernünftigen Wesens befördern werde, völlig unauflöslich, mithin kein Imperativ in Ansehung derselben möglich sei, der im strengen Verstande geböte, das zu thun, was glücklich macht, weil Glückseligkeit nicht ein Ideal der Vernunft, sondern der Einbildungskraft ist, was bloc auf empirischen Gründen berubt, von denen man vergeblich erwartet, daß sie eine Handlung bestimmen sollten, dadurch die Totalität einer in der That unendlichen Reibe von Folgen erreicht würde. [Grundlegung zur Metaphysike der Sitten (1785). Kapitel: II. Übergang von der populären sittlichen Weltweisheit zur Metaphysik der Sitten. Basis-Ausgabe: Akad. (1905ff.), S. IV:418. Bis: S. IV:419.] 
cuestión del tipo de ideal del que estamos hablando, recurramos a la sección de la Dialéctica Transcendental de la Crítica de la razón pura titulada "El ideal en general" (A570/B598). Allí encontramos la contraposición entre el ideal de la razón, que actúa como arquetipo (Urbild) dotado de fuerza práctica, como por ejemplo el ideal del sabio estoico, y el "impropiamente llamado ideal de la sensibilidad" o "creación de la imaginación" (Geschöpf der Einbildungskraft). Es aquí donde creo que podemos reconocer el ideal de la imaginación, ${ }^{36}$ tanto si escogemos uno de los nombres de cada uno de estos dos apelativos y los unimos, como si atendemos a sus rasgos constitutivos:

Este es también el caso del ideal de la razón, que siempre descansa en conceptos determinados y ha de servir como regla y arquetipo, sea para seguirla o para el enjuiciamiento. Muy otro es el caso de las criaturas de la imaginación, sobre las cuales nadie puede explicarse ni dar un concepto comprensible de ellas, como monogramas, que sólo son rasgos sueltos ciertamente no determinados por ninguna regla que pueda suministrarse, que producen algo más similar a un dibujo que flota en el medio de experiencias diversas que a una imagen determinada, parecido a lo que los pintores y fisonomistas pretenden tener en la cabeza y que debe ser una silueta no compartible de su producto o también de su enjuiciamiento. Pueden llamarse, aunque impropiamente, ideales de la sensibilidad, ya que han de ser el modelo inalcanzable de intuiciones empíricas posibles, si bien no ofrecen ninguna regla susceptible de explicación ni de examen.

El propósito de la razón con su ideal es, por el contrario, la determinación general de acuerdo con reglas a priori; a partir de ahí ella piensa un objeto que debe ser determinable en general según principios, aunque falten en la experiencia condiciones suficientes para ello y entonces su concepto mismo sea trascendente. ${ }^{37}$

\footnotetext{
36 Sarah Gibbons presenta una interpretación completamente distinta de este pasaje y de la nuestra respecto al problema de los ideales de la razón y de la imaginación (Kant's Theory of Imagination, Bridging Gaps in Judgment and Experience. Oxford: Oxford University Press, 1994 (2002), p. 99-101). Para ella el ideal de la sensibilidad del que habla de Crítica de la razón pura pertenece a la imaginación reproductiva, pues en el texto se dice que el monograma es extraído de la experiencia, mientras que el ideal de la imaginación productiva sería el ideal de la imaginación que aparece en el $\int 17$ de la Crítica del Juicio, dado que allí se dice que el arquetipo del gusto nos esforzamos por producirlo en nuestro interior sin que podamos encontrar ningún caso en la experiencia. Nos parece que la división exterior/interior en Kant no se corresponde con las funciones reproductivas y productivas de la imaginación. Por otra parte, Kant también habla de monogramas cuando en la Crítica del Juicio se refiere al poder productivo de la imaginación.

37 So ist es mit dem Ideale der Vernunft bewandt, welches jederzeit auf bestimmten Begriffen beruhen und zur Regel und Urbilde, es sei der Befolgung oder Beurtheilung, dienen muß. Ganz anders verbält es sich mit den Geschöpfen der Einbildungskeraft, darüber sich niemand erklären und einen verständlichen Begriff geben kann, gleichsam Monogrammen, die nur einzelne, obzwar nach keiner angeblichen Regel bestimmte Züge sind, welche mehr eine im Mittel verschiedener Erfahrungen gleichsam schwebende Zeichnung, als ein bestimmtes Bild ausmachen, dergleichen Maler und Physiognomen in ihrem Kopfe zu haben vorgeben, und die ein nicht mitzutheilendes Schattenbild ibrer Producte oder 
El ideal de la razón es completamente (durchgängig) determinable por reglas a priori, es decir, la razón puede transitar por él sin problemas. El ideal de la imaginación, en cambio, carece de esta determinación, por lo que solamente presenta un dibujo impreciso de trazos sueltos y cambiantes que no constituyen una imagen. Aunque el texto no aluda a ninguno en concreto, podemos reconocer en él la oscilación y la imprecisión que veíamos en aquel texto de la Fundamentación de la metafísica de las costumbres en el que Kant iba desgranando los sucesivos fracasos acaecidos a partir del intento de definir la felicidad. Y también reconocemos la Mannigfaltigkeit del Canon de la Crítica de la razón pura, esa multiplicidad de pliegues que hacía imposible un trazado preciso del deseo. Ahora insiste Kant en un resultado de todo esto: la imposibilidad de que un concepto tan borroso pueda ser explicado, comprendido, comunicado; en una palabra, su resistencia al discurso lógico. Mientras el ideal de la razón tiene una utilidad doble, pues sirve como regla rigurosa para orientar la acción y como criterio para la valoración o enjuiciamiento, el ideal de la imaginación, por su impenetrabilidad al lógos, porque el lógos no puede circular libremente por él, tiene vedados estos procesos y no puede trascender más allá de un lenguaje privado, no puede hacerse de dominio público. ${ }^{38}$ Aunque sigue valiendo como orientación y como valoración, pone de manifiesto otra forma de actuar y de enjuiciar que no puede ser común. Esta es la explicación de por qué en este ámbito no existen reglas ni mandatos, sino solamente consejos.

Ahora bien, el texto que estamos comentando añade algo más. Es cierto que no se puede explicar el ideal de la imaginación ni se puede traducir a un

auch Beurtheilungen sein sollen. Sie können, obzwar nur uneigentlich, Ideale der Sinnlichkeit genannt werden, weil sie das nicht erreichbare Muster möglicher empirischer Anschaunngen sein sollen und gleichwobl keine der Erklärung und Prüfung fähige Regel abgeben. Die Absicht der Vernunft mit ibrem Ideale ist dagegen die durchgängige Bestimmung nach Regeln a priori; daber sie sich einen Gegenstand denkt, der nach Principien durchgängig bestimmbar sein soll, obgleich dazu die hinreichenden Bedingungen in der Erfahrung mangeln und der Begriff selbst also transscendent ist. [Kritik der reinen Vernunft (1787). Kapitel: 2. Buch der tr. Dialektik. 3. Hauptst. Das Ideal der reinen Vernunft. 1. Abschn. Von dem Ideal überhaupt. Basis-Ausgabe: Akad. (1905ff.), S. B:598. Bis: S. B:599]

${ }^{38}$ Así, Birgit Recki interpreta que "[...] en razón de la indeterminación que le es propia tanto por la complejidad individual como por la ambigüedad subjetiva de las representaciones enlazadas con ella, Kant determina la felicidad en la Fundamentación de la metafísica de las costumbres al mismo tiempo como »ideal de la imaginación« (GMS IV, 418). Si se pone en relación este origen en la imaginación y la inagotable multiplicidad de significados de sus representaciones con el agrado en la mera representación, que inevitablemente está presupuesto en la descripción de Kant, y que — teniendo en cuenta el carácter y la multiplicidad de significados constitutiva de la representación — no se puede identificar con un mero agrado de los sentidos, entonces el carácter estético de la representación de la felicidad resulta sorprendente" (Ästhetik der Sitten: die Affinität von ästhetischem Gefühl und Praktischer Vernunft bei Kant, ed. cit., p. 132). El ideal de la imaginación tendría que ver, pues, más con el ámbito de la estética que con el de la razón pura. Ahora bien, siguiendo este hilo lo que vamos a encontrar es que aquí también es posible trascender el lenguaje privado. 
concepto que resulte comprensible. Pero nos queda otro recurso, pues no hay que olvidar que lo que ocurre con el ideal de la razón es que, aunque sí permite hacer todo eso, no se deja presentar en una imagen. Sería absurdo representar al sabio estoico, que es un ideal de la razón, en una novela, porque ese amigo manso, aparte de resultar irrisorio, en seguida se haría sospechoso y se podría pensar que es lo que Kant llama una "pura ficción" (blosse Erdicbtung). La razón es que no se puede representar una idea, pues “[...] las barreras (Schränke) naturales que continuamente perjudican a la completud en la idea hacen imposible toda ilusión en semejante ensayo". ${ }^{39}$ No se puede sensibilizar una idea porque la ilusión que se intenta conseguir al construir una representación sensible de ella no es edificante (erbaulich), pero tampoco edificable. Y la razón es que en el ámbito de los fenómenos, de la experiencia, nos encontramos con obstáculos, con trabas, con barreras externas siempre renovadas que impiden construir la absolutez de la idea. Y, por el contrario, sí se puede sensibilizar de alguna manera el ideal de la imaginación, o al menos algunos de sus rasgos, pues precisamente este magma flotante es el terreno de la ficción que no es "pura ficción": de la producción artística o poética. Aquí se puede trabajar con alusiones, con sugerencias, más que con monogramas con metáforas, que trasponen un sentido siempre huidizo en imágenes o intuiciones empíricas posibles, como dice el texto. Si la imaginación no puede explicar y hacer lógicamente comprensibles estas criaturas suyas, lo que sí puede hacer con ellas es presentarlas en esa novela en la que el ideal de la razón no tenía nada que hacer. Allí donde fracasa la lógica aún queda la

\footnotetext{
39 Que el ideal del sabio estoico representado resulta ridículo ya lo sabía muy bien Nietzsche. Y por eso mismo lo representa en el memorable final de Sobre verdad y mentira en sentido extramoral (op.cit. Bd. 1, p. 889-890). Nos encontramos allí la personificación del sabio estoico, que es el hombre racional que se guía por conceptos, en contraste con la del hombre intuitivo, que podría corresponder a ese artista al que se está refiriendo veladamente el texto que venimos comentando. La contraposición entre ideal de la razón y criatura de la imaginación la volvemos a encontrar en Nietzsche convertida en el enfrentamiento entre el hombre racional y el intuitivo. Nietzsche ensaya, pues, a encarnar la idea y así pone de manifiesto las barreras sensibles que la hacen estallar. Estas se cifran en el cambio de circunstancias, más concretamente, en el advenimiento de la desgracia. En este momento es cuando la imagen del sabio se muestra como la "[...] obra maestra del fingimiento" (Meisterstück der Verstellung) y su rostro, como una máscara de rasgos inhumanos. En la desgracia el sabio se revela como pura ficción inverosímil, irrisoria y sospechosa. Nietzsche no sólo corrobora en este texto lo que ya dijo Kant en el suyo, sino que nos hace el precioso favor de recordarnos que las barreras naturales que impiden construir la idea de la razón guardan relación con el problema de la felicidad, pues, al cambiar el decorado haciendo huir la felicidad y presentarse la desgracia, nos está señalando cuál es el escenario de fondo en el que toda esta historia se está jugando o se está representando: el de la dicha y la miseria, el de la rueda de la fortuna. Es en este escenario continuamente giratorio en donde el ideal del sabio estoico no se puede construir, pues pasa de ser sublime a ser ridículo, de ser persona a ser personaje o máscara hueca.
} 
narración. Cuando una cosa no se entiende se cuenta su historia, ${ }^{40}$ esa historia que recrea el tiempo fenoménico introduciendo en él aquello que no es verdad, pero tampoco es absolutamente falso, sino que es similar a la verdad y cómplice, al mismo tiempo, de nuestros deseos. Y lo hace mediante un procedimiento sesgado y alusivo que va traduciendo en imágenes el material que se fragua en medio de experiencias diversas. La alusión al monograma es interesante, pues en un monograma está extractada y sintetizada al máximo una experiencia compleja y este material tan variado pasa a ser convertido en un único trazo o en una escritura única que compendia una totalidad inabarcable. ${ }^{41}$

Pues bien, es esta silueta (Schattenbild) o imagen en sombra - en negativo-, esta no-imagen matriz de las imágenes, esta fuente cuya fecundidad da origen a las diversas construcciones de la imaginación, la que estamos buscando en este trabajo. Entendemos por qué no es determinada, pues solo lo indeterminado puede ser origen de cualquier determinación. Vamos entendiendo ahora también por qué es privada, no compartible, no comunicable: por qué es una imagen en negro o en la sombra. Y también nos vamos dando cuenta de que, fuera de un procedimiento indirecto, no hay otra manera de acceder a la idea de la felicidad.

Para definir lo que es el ideal Kant lo contrapone a la idea en términos de su mayor o menor realidad objetiva. El ideal tiene aún menor realidad objetiva que la idea, pues se define como una idea in individuo, como una cosa singular que

${ }^{40}$ Entender completamente una cosa significaría poder nombrarla con un nombre tan ajustado a ella que fuera verdaderamente y en todos los sentidos su nombre propio. "Si se pudiera dar un nombre a todo lo que sucede, sobrarían las historias. Tal y como son aquí las cosas, la vida suele superar a nuestro vocabulario. Falta una palabra, y entonces hay que relatar una historia" (BERGER, John. La era de los cosmonautas, en Una vez en Europa, Madrid, 1991, p. 89). Así, la literatura nace de la impotencia de nombrar y de la incapacidad de entender. Sobre la noción de verosimilitud, véase: PARDO, J. L. La regla del juego. Sobre la dificultad de aprender filosofía. Barcelona: Círculo de lectores, 2004, p. 564-565, especialmente cuando afirma, a propósito de Platón, que la narración verosímil es aquella que, consciente de sus límites, sabe cuándo detenerse, pues se da cuenta de que la idea es inimitable y, por eso mismo, sólo puede tener imitaciones de las que se sepa que lo son, imágenes en las que no se pretenda eliminar su distancia con respecto al modelo. Pretender presentar en serio, directa e inmediatamente, sin ironía, el ideal de la razón, es inverosímil.

${ }^{41}$ Rudolf A. Makkreel observa que “[...] en su uso más común un monograma es una configuración de letras o iniciales que sustituyen a un nombre. De forma similar, la síntesis figurativa de la imaginación puede ser explicada en términos lingüísticos tanto como matemáticos." (Imagination and Interpretation in Kant: the Hermeneutical Import of the Critic of Judgment. Chicago: University of Chicago Press, 1994, p. 32.) A nosotros nos interesan los primeros, desde luego. Los segundos son los mencionados en la Crítica de la razón pura A142/B181 dentro de la explicación de la síntesis especiosa o figurativa. Hay que advertir que el monograma ocupa el lugar de un nombre que — añadimos nosotros - no vamos a encontrar nunca. Nunca vamos a tener en nuestras manos otra cosa más que las letras y el procedimiento o el juego mismo: nada sustantivo. En cuanto al interesantísimo libro de Makkreel, en el que se reivindica el papel hermenéutico de la imaginación, lo que pretendemos en este artículo es ampliar su tesis al problema de la felicidad. 
únicamente se determina a partir de la idea. En vez de determinarse sobre la base de la experiencia, como los conceptos, o sobre la base de los conceptos, como las ideas, el ideal se determina sobre la base de las ideas. El ideal de la humanidad, por ejemplo, contiene "[...] también todo aquello que, aparte de este concepto [de humanidad], pertenece a la total (durchgängige) determinación de la idea, pues de todos los predicados contrapuestos sólo uno puede convenir a la idea del hombre perfectísimo". Se trataría, entonces, del ideal del hombre, ajustado a la idea de tal manera porque surge de la realización de aquella operación racional que consiste en enjuiciar, de cada par de enunciados unidos por una disyunción excluyente, cuál es el que le corresponde de acuerdo con el ser de la idea. El resultado, el ideal de hombre perfecto, funciona a su vez como Urbild, como imagen originaria, como arquetipo, para el enjuiciamiento de las cosas sensibles — que, desde este punto de vista, son Nacbbilder, copias o imitaciones- El ideal, pues, es una construcción racional en la que la idea ensaya su trabajo de la determinación cumplida o absoluta; es el resultado del trabajo de la idea.

Esto es todo lo que nos dice Kant sobre la noción de ideal. Nuestra tarea consiste ahora en referir estos rasgos al ideal, no de la razón, sino de la imaginación. Éste, entonces, habría que considerarlo como una construcción de la imaginación a la que podrían aplicarse uno de cada pareja de términos contrapuestos dentro de una misma esfera. Ahora bien, ¿qué idea nos daría el criterio para decidir en este caso?, ¿qué idea nos serviría para determinar completamente el ideal? ¿No hemos comprobado ya que nos encontramos ante un concepto - no ante una ideaen sí mismo indeterminado? Así, cada vez que queremos decidir entre parejas de términos contrapuestos dentro de la misma esfera, fluctuamos entre ellos en lugar de llegar a una conclusión, de manera que el procedimiento que funciona en el caso del ideal de la razón se revela en este caso como inoperante. Lo único que obtenemos es ese trazo inseguro y vacilante, ese dibujo en ciernes del que ya hemos hablado anteriormente. Y, en efecto, el modo de trabajar de la imaginación en su ideal ha de ser forzosamente diferente del de la razón en los suyos. Si llamamos a la felicidad ideal de la imaginación no será, entonces, porque haya surgido del mismo procedimiento que el ideal de la razón, sino porque, en cuanto ideal, es también una construcción singular sin realidad objetiva y dotada de fuerza práctica.

Pero, ¿cómo sería un ideal de la imaginación? Sabemos que no puede ser algo completamente inventado, pues "[...] incluso aunque la imaginación sea una tan grande artista e hasta maga, no es creadora, sino que ha de sacar de los sentidos la materia para sus imágenes". ${ }^{42}$ Precisamente la presencia de las inclinaciones, las pulsiones, los afectos, etc., hace que el ideal de la imaginación no pueda ser, como

${ }^{42}$ Anthropologie in pragmatischer Hinsicht (1798). Kapitel: Von der Einbildungskraft. Basis-Ausgabe: Akad. (1905ff.), S. VII:168. 
el ideal de la razón, la representación en concreto de una idea. Pues lo que falta es la idea.

Ahora bien, nosotros sabemos que la imaginación puede trabajar sin idea. Sabemos incluso que esta es la forma en que su trabajo es más libre, más propio, más espontáneo. Dudamos sobre si debe aplicársele la palabra trabajo y le llamamos a veces juego. Pero eso no significa que deje de ser una actividad. Pues bien, si la actividad más propia de la imaginación se desarrolla sin una idea previa pero tomando como material lo sensible, tal vez el ideal de la imaginación haya que pensarlo como la representación, no de una idea, sino de una acción. Esta acción sería aquella en la que la imaginación productiva labora en su máxima potencia pero sin llegar al delirio. ${ }^{43}$ Esta actividad, aunque sea un juego libre, no puede dejar de ser productiva. Sus producciones no son imágenes concretas, sino fluctuantes, como imágenes que son matrices de otras imágenes. Y ¿no podrían ser algunas de estas imágenes o ídolos de la imaginación aquellos discursos de la felicidad que hemos estado presentando? En realidad ninguna de ellas tiene por qué ser el tan buscado ideal, pues tal vez el ideal, como estamos diciendo, no sea una imagen en concreto, sino la diversidad misma no clausurada, no satisfecha, no cerrada, de la cual aquella colección de imágenes no sería más que una muestra, una galería de retratos incompleta que la historia de nuestra cultura ha ido fraguando como modelos de lo amable. Esta diversidad, trasunto de la Mannigfaltigkeit sensible, no puede dejar de tener, como ella, arrugas y pliegues.

La actividad de la imaginación de la que estamos hablando se adapta, en efecto, al procedimiento que se expone en la Crítica del Juicio ${ }^{44}$ según el cual ella proyecta rápidamente una multitud de imágenes y obtiene un modelo a partir de

${ }^{43}$ La originalidad (la producción no imitativa) de la imaginación que concuerda con conceptos se denomina genio; la que no concuerda, delirio (Schwärmerei).— - Ibid. Kapitel: Von der Einbildungskraft. Basis-Ausgabe: Akad. (1905ff.), S. VII:172]

${ }^{44}$ [Kritik der Urtheilskraft (1790). Basis-Ausgabe: Akad. (1905ff.), V: 234] Es curiosa la repetición casi idéntica de la expresión "imagen fluctuante" en el texto de la Crítica de la razón pura que hemos analizado. A propósito de estos dos textos y de lo que hemos ido comentando sobre ellos, cabe otra interpretación completamente diferente como la que defiende Sarah Gibbons (Kant's theory of imagination. Bridging gaps in Judgement and Experience. Oxford: Clarendon Press, 1994 (2002), p. 99100). Según ella, Kant en la Crítica de la razón pura defiende la existencia de un ideal de la razón y de un ideal de la sensibilidad y posteriormente, en la Crítica del Juicio, introduce un tercer tipo de ideal, a saber, el de la imaginación. Nosotros, en cambio, hemos mantenido que el ideal de la sensibilidad de aquella obra es el ideal de la imaginación de ésta o, al menos, un precedente suyo. Asumimos, pues, más bien la interpretación de Rudolf A. Makkreel, que identifica sin más lo dicho en los dos textos que estamos comentando, aunque le interesa más la deriva histórica de Kant entre los dos. Dentro de su análisis del $\$ 17$ de la Crítica del Juicio, señala: "Los productos de la imaginación habían sido descritos en términos similares en la primera Crítica [...] De hecho, la idea normal estética es comparable al monograma matemático de los conceptos sensibles puros en la medida en que ambos envuelven una regla para la construcción de una figura y no son reducibles a una imagen empírica particular. Sin embargo, 
lo que tienen en común todas ellas. La diferencia estaría en que aquí no tenemos imágenes concretas que proyectar, como en la formación de la idea normal, sino que tenemos solamente el procedimiento; a falta de figuras que engastar, nos quedamos con la pura forma de relación entre ellas, que a su vez rinde esa serie inconclusa de imágenes que hemos venido describiendo. En este caso la imaginación funciona en libertad, explorando afinidades entre las experiencias, y no estableciéndolas entre los conceptos, pues en esta ocasión le faltan los conceptos. Y si nos maravillamos de que se pueda establecer una hermandad entre discursos tan dispares como el de la felicidad del instinto y la de la cultura, por ejemplo, recordemos que era aún más extraño que se pudieran relacionar o hermanar la sensibilidad y el entendimiento, pero, sin embargo, la imaginación las hacía brotar de su misma raíz. Sabemos también que si estamos en el terreno de la conexión, de la síntesis, de la imaginación, es porque nos movemos en el ámbito del juicio, de esa facultad que subsume lo particular en lo universal o de alguna manera le busca al particular un universal. Y no nos debe desanimar el hecho de que aquí carezcamos de universales. Tal vez no nos hagan falta si existe una epigénesis de la felicidad.

\title{
FELICIDAD A PRIORI
}

En el texto de la Reflexión 7202 encontramos el siguiente fragmento:

\begin{abstract}
El único capaz (fähig) de ser feliz es aquel que usa su arbitrio de manera que no sea contrario a los data que para la felicidad le da la naturaleza. Esta propiedad del arbitrio libre es la conditio sine qua non de la felicidad. En realidad la felicidad no es la mayor suma del disfrute, sino el placer (Lust) que surge de la conciencia del propio poder (Selbstmacht) para ser feliz. Esta es, al menos, la condición esencialmente formal de la felicidad, si bien aún son exigibles otras materiales (como en la experiencia). ${ }^{45}$
\end{abstract}

El texto no habla de la felicidad, sino de la capacidad para ser feliz, de la condición formal de la felicidad, del poder que reside en uno mismo y solamente bajo el cual se puede sentir placer. Y pone en paralelo la consecución de la felicidad con la adquisición del conocimiento. Los datos de la naturaleza en este caso pertenecen a otra experiencia que es la experiencia del deseo, con sus inclinaciones, pasiones, sentimientos y pulsiones. Del mismo modo que en

sus diferencias son indicativas de cómo las funciones mediadoras de la imaginación son revisadas desplazándolas desde la lectura de la experiencia a su interpretación reflexiva”(op. cit., p. 115).

45 Reflexionen zur Moralphilosophie. Kapitel: [Nachlaß] Phase psi. Basis-Ausgabe: Akad. (1905ff.), S. XIX:276. Bis: S. XIX:282, n ${ }^{\circ}$ 7202. En este apartado volveremos a este texto a menudo sin que sea preciso anotar su referencia. Los resaltados en negro son míos. 
el conocimiento hay que respetar los datos de la experiencia y conformarlos de acuerdo con unos conceptos y unos principios a priori, ¿no podría consistir el apriorismo de la felicidad en proporcionar un marco en el cual esa naturaleza, lejos de ser ignorada, pudiera desarrollarse, vivir, fructificar? Desde luego, parece ser que lo que no se puede hacer es ignorarla. Tampoco parece que sea oportuno someterse a ella. Por eso lo que estamos intentando ahora es darle un estatuto: el de elemento material del uso de nuestro arbitrio, como la experiencia es el elemento material del uso de nuestro entendimiento en el conocimiento, aquel al que necesariamente ha de referirse si de verdad ha de querer o conocer algo. La felicidad sería capaz de producirse a sí misma respetando toda la indeterminación de nuestras inclinaciones si consiguiera proporcionarles un marco en el cual ellas pudieran ser lo que son naturalmente.

En textos como el que estamos comentando Kant propone una felicidad formal, intelectual, que no depende de las condiciones naturales aunque tenga que respetarlas, sino que ha de ser ella misma la determinante. Se trata de una felicidad activa: la acción de ser feliz. La felicidad, así entendida, es a priori. Vamos a intentar tomarnos absolutamente en serio estas palabras. Y para ello vamos a dar un rodeo por el texto de la Crítica de la razón pura en el que Kant se plantea la cuestión de cómo se puede pensar la concordancia de la experiencia con los conceptos puros. En principio aparecen dos posibilidades: “[...] o bien la experiencia hace posible estos conceptos o estos conceptos hacen posible la experiencia". ${ }^{46}$ La conclusión a la que llega es que las categorías son a priori y, por tanto, son ellas las que hacen posible la experiencia. La posibilidad contraria sería una especie de generatio aequivoca de los conceptos. Excluido el preformacionismo, de raíz innatista, sólo se puede defender la epigénesis de la razón pura, que afirma que "[...] las categorías del lado del entendimiento contienen los fundamentos de la posibilidad de toda experiencia en general". Pues bien, en este texto Kant está precisando lo que a nuestro juicio hay que entender cuando se indica que la felicidad es a priori. Y lo está haciendo en polémica con la afirmación de que procede de la experiencia, por una parte, y en oposición asimismo con la tesis que afirma que procede de una instancia superior a nosotros que nos ha puesto una disposición originaria o un germen del que ella debe brotar. La primera sería la tesis empirista de la felicidad y la segunda sería equivalente a esa vía intermedia (Mittelweg) que pretende que los principios del conocimiento estarían implantados en nosotros por nuestro creador como unas disposiciones para el pensamiento (Anlagen zum Denken). Pero en tal caso las categorías carecerían de la necesidad objetiva que les pertenece esencialmente y solo tendrían una necesidad subjetiva

${ }^{46}$ Kritike der reinen Vernunft (1787). Kapitel: \27. Resultat dieser Deduction der Verstandesbegriffe. Basis-Ausgabe: Akad. (1905ff.), S. B:166. Bis: S. B:168. 
y, en el fondo, arbitraria. "Yo no podría decir: el efecto está unido con la causa en el objeto (esto es, necesariamente), sino yo estoy organizado (eingerichtet) de tal manera que no puedo pensar esta representación de otro modo que asi conectada". Esta postura preformacionista es precisamente la que el escepticismo está esperando oír.

Si ahora sustituimos las categorías por la felicidad —al fin y al cabo es Kant mismo el que está haciendo en la Reflexión 7202 la comparación que aquí indicamos, el que está poniendo en paralelo continuamente el apriorismo de la felicidad con el del conocimiento-, la generatio aequivoca estaría representada por los que entienden la felicidad exclusivamente en su aspecto material y para los que la felicidad siempre será una ilusión y un concepto indeterminado. El preformacionismo estaría representado por los identitarios, por aquellos que consideran que la posibilidad de ser feliz está implantada de suyo en la acción cuando esta es virtuosa. ${ }^{47} \mathrm{Y}$ Kant estaría manteniendo la epigénesis de la felicidad, según la cual existe una felicidad que es a priori y es ésta la que, estando de lado del sujeto, actúa como condición de posibilidad de toda felicidad empírica posible de tal manera que no podría haber felicidad si no se atuviera a esas condiciones. Y, en efecto, eso es lo que defiende en algunas Reflexiones de los años 1776-1778, en las que se refiere a la epigénesis de la felicidad asociándola con la autocreación (Selbstgeschöpf). ${ }^{48}$ El hecho de que allí se diga que esta autocreación de la felicidad tiene lugar a partir de la libertad (aus der Freibeit) no debe engañarnos; la aparente contradicción se disuelve si tenemos en cuenta que se está hablando de la libertad, es decir, de aquello que precisamente es una generación a partir de sí misma. Así, "[...] la felicidad carece de valor estable en tanto que es un don de la naturaleza o de la suerte" - esto es, en tanto que felicidad de generatio aequivoca - y solo lo tiene como conciencia de la autoposesión de las fuentes de la felicidad (Selbstbesitz der Qvellen der Glïkseeligkeit), es decir, como felicidad formal o a priori.

Esto no significa que no exista la felicidad material, como tampoco el hecho de que existan los conceptos puros del entendimiento implica que se pueda prescindir de los datos del conocimiento; pero no hay que olvidar que si lo a priori está del lado del sujeto y en este caso estamos refiriéndonos a un a priori práctico, éste tendrá que consistir necesariamente en una acción que sea previa a toda acción. Pues bien, Kant está intentando conciliar aquí esta acción previa a toda acción con la receptividad que caracteriza a la finitud sensible.

No se puede lograr un apaciguamiento completo de los sentidos, ni siquiera se puede determinar con certeza y universalmente lo que sea adecuado a sus

\footnotetext{
${ }^{47}$ En este texto Kant se enfrenta sobre todo a esta última postura, que, forzando la comparación entre los textos, podríamos denominar el escepticismo de la felicidad.

48 Reflexionen zur Moralphilosophie. Kapitel: [Nachlaß] Phase ypsilon-phi. Basis-Ausgabe: Akad. (1905ff.), S. XIX:185-186, nº 6864, 6865 y 6867.
} 


\begin{abstract}
exigencias; ellos siempre acrecientan sus requerimientos y están insatisfechos sin poder decir qué es lo que los colmaría. Aún está menos asegurada la posesión de este disfrute por causa de la mutabilidad de la fortuna y la casualidad de las circunstancias favorables y de la brevedad de la vida. Pero la disposición (Gesinnung) adiestrada mediante la razón para servirse bien y cabalmente de todos los materiales para el bienestar es cierta a priori, se deja reconocer completamente y nos pertenece a nosotros mismos de tal modo que incluso la muerte, que es un estado pasivo, no puede disminuir su valor. [...]
\end{abstract}

Y lo encuentra en la Gesinnung, en la disposición de ánimo, en la una intención especial que sabe servirse o usar adecuadamente el material de la felicidad. Es un aprestarse, un modo de usar las cosas que abre y determina lo que ellas puedan ser para nosotros y que, como formal y a priori, nos pertenece enteramente. Un poco más adelante la denomina apperceptio iucunda. Y también, en cuanto es el elemento a priori de un sentimiento, podemos afirmar que es un a priori sentimental. En cualquiera de sus nombres la felicidad a priori no se obtiene de la experiencia pero está inevitablemente referida a ella como condición de posibilidad suya.

Pues bien, si, como todo a priori, esta felicidad formal debe residir del lado del sujeto, encontramos que es la imaginación la instancia donde únicamente puede tener su asiento. En nuestro trabajo hemos ido encontrando los modos en que la imaginación produce figuras que pretenden dar forma a ese fondo de inclinaciones, afectos, disposiciones, en que consiste la finitud humana. Esa actividad de configuración considerada en sí misma, y no las imágenes que resultan de ella, es lo que constituye el ideal de la imaginación, que también hemos comprobado que no puede ser un ideal como lo es el de la razón. Por el contrario, se caracteriza por la multiplicidad, por la indeterminación, por estar continuamente en proceso. Cuando analizábamos los diversos discursos de la felicidad comprobábamos que parecía que no estábamos hablando de la misma felicidad. Ahora vemos que no es extraño, pues la felicidad se dice de múltiples maneras, como todo lo que cae dentro del dominio de la imaginación, un terreno en el que no cabe hablar de mismidad, sino de ese dibujo fluctuante que nos atrae, que enlaza y desenlaza la trama de nuestros deseos y de nuestra fascinación, cuya belleza nos encanta. La felicidad es el ideal de la imaginación porque contiene todos los rasgos que encontramos funcionando en cada uno de sus usos: el uso teórico, el uso práctico, el uso estético — de la imaginación - se caracterizan, en efecto, por aquello que encontramos llevado al máximo en la felicidad formal, en lo formal de la felicidad.

$\mathrm{Al}$ inventar la felicidad, esa ficción necesaria, la imaginación ensaya su máxima libertad, su completa desenvoltura. Pero también hemos comprobado que al hacerlo no está vacando ociosa al terreno del juego, sino que está poniendo 
en juego aquello que más le importa al hombre. ${ }^{49}$ No es evasión: es apropiación. En la creación de la idea de la felicidad nos lo jugamos todo. Se trata del juego más serio y más abismal porque se trata del juego con la muerte, es decir, con la finitud humana. De ahí que la felicidad en sentido formal —y solamente ellasea imperativa. La felicidad a priori o formal no es concepto ni intuición, sino tarea y problema.

FERRER, S. G.. Happiness as Imagination's Ideal. Trans/Form/Ação, Marília, v. 34, n.2, p. 21-52, 2011.

ABSTRACT: In this article, we develop minimally five discourses about the happiness we find in Kant's work. We hardly met them because they are not ordered or continued speeches throughout his pages, but suggestions that appears from time to time, between the lines of other reflections. Happiness is designed as totality, as an undefined concept, as the opposite corner of culture, and as feeling and wellness. Although not involving linked speeches, it is possible to follow its tracks throughout the text. However, there is another suggestion that Kant gives us without having developed entirely: according to that, happiness would be the ideal of imagination. This non pronounced speech could be the key to find consistency of others.

KEYWORDS: Imagination. Ideal. A priori.

Recebido em: 5 de abril de 2011

Aprovado em: 29 de junho de 2011

${ }^{49}$ Reflexionen zur Moralphilosophie. Kapitel: [Nachlaß] Phase psi. Basis-Ausgabe: Akad. (1905ff.), S. XIX:272, no 7199 .

Trans/Form/Ação, Marília, v. 34, n. 2, p. 21-52, 2011 